Journal of

Ecology 2006

94, 548-557

\title{
Previous land use alters plant allocation and growth in forest herbs
}

\author{
JENNIFER M. FRATERRIGO*, MONICA G. TURNER and \\ SCOTT M. PEARSON† \\ ${ }^{1}$ Department of Zoology, University of Wisconsin, Madison, WI53706, USA, and † Department of Biology, Mars Hill \\ College, Mars Hill, NC 28754, USA
}

\begin{abstract}
Summary
1 Former human practices can persistently influence forest ecosystems, particularly by altering the distribution and abundance of vegetation. Previous research has focused on the role of colonization success in governing plant community patterns in abandoned forests, but few studies have explored how changes in the performance of adult plants may contribute to changes in plant populations.

2 We examined patterns of biomass allocation and growth of 12 herbaceous plant species in southern Appalachian forest stands that have developed after agricultural abandonment or logging at least 55 years ago, to determine whether plant performance varied with land-use history. Soil nutrient availability and canopy closure were also investigated.

3 Adult plant biomass allocation varied appreciably among stands with different histories. Herbs in farmed stands generally allocated the most to leaves and the least to stems, while reference stands showed the opposite pattern. Plants in previously farmed sites had the highest rate of growth, although we observed considerable interspecific variation in plant performance. Stem allocation and relative growth rate were positively correlated in reference stands, but not in farmed or logged stands. Similarly, the growth of plants was clearly associated with soil nutrient concentration in reference stands but not in farmed or logged stands.

4 Differences in understorey density and soil nutrient availability may account for the observed patterns. Total herbaceous cover was appreciably lower in farmed and logged stands $(58 \%$ and $51 \%)$ than in reference stands $(78 \%)$, and soil phosphorus was higher in farmed stands than in logged and reference stands. Thus, competition for light and nutrients may be lower in farmed and logged stands than in reference stands, despite there being no difference in canopy closure with land-use history.

5 Overall, these results suggest that land-use history may influence environmental variables in ways that can enhance the performance of some herbaceous species. However, not all species may respond similarly to these changes.
\end{abstract}

Key-words: allometry, biomass, growth rate, land-use history, leaf area, optimal partitioning, understorey, southern Appalachians USA.

Journal of Ecology (2006) 94, 548-557

doi: $10.1111 / \mathrm{j} .1365-2745.2005 .01081 . \mathrm{x}$

\section{Introduction}

Although it is well established that human disturbance influences the structure and function of plant communities,

(C) 2006 The Authors Journal compilation (C) 2006 British Ecological Society
*Present address and correspondence: Jennifer M. Fraterrigo (Department of Ecology, Evolution and Organismal Biology, 253 Bessey Hall, Iowa State University, Ames, IA 50011, USA, e-mail jmfrater@iastate.edu). understanding its role in determining the trajectory of vegetation recovery remains a fundamental need in ecology. Human disturbances can vary in size, intensity and longevity. The effects of disturbance on vegetation recovery will depend not only on these characteristics, but also on how disturbance modifies landscape pattern and resource availability, as well as on the inherent abilities of plant species to either survive the disturbance or recolonize disturbed areas (Roberts \& Gilliam 2003). 
Past land use and plant allocation and growth

(C) 2006 The Authors Journal compilation (C) 2006 British Ecological Society, Journal of Ecology, 94, 548-557
Lands abandoned from agriculture or silviculture offer a unique opportunity to investigate the relative importance of these factors in shaping the trajectory of vegetation recovery. Such practices have profound but differential effects on the abundance and distribution of forest plant communities, which can persist for decades, or even centuries, following the cessation of human activities (Flinn \& Vellend 2005). In eastern North America and Europe, for example, agricultural practices abandoned more than 30 years ago have been shown to account for the loss or reduced abundance of at least 50 herbaceous species (Peterken \& Game 1984; Dzwonko \& Loster 1992; Motzkin et al. 1996). The effect of clearcutting tends to be less straightforward, with some studies showing long-term detrimental impacts on the herb layer (Duffy \& Meier 1992) and others finding short-lived or highly site-dependent changes (Roberts \& Gilliam 1995). Empirical observations and models strongly support the hypothesis that many herbs are slow or unable to recolonize suitable habitat due to constraints associated with dispersal mode, clonal expansion, diaspore production or habitat isolation. Wind- and vertebrate-dispersed species tend to have higher migration rates than species dispersed by ants and those that lack morphological adaptations for dispersal (Dzwonko \& Loster 1992; Matlack 1994; Brunet \& von Oheimb 1998), and are consequently more abundant in altered stands. Similarly, species with rapid clonal expansion and large numbers of seeds tend to be more frequent in altered stands (Eriksson 1995; Singleton et al. 2001; Mabry 2004). Stand age and distance from source habitat can interact with dispersal and further limit the colonization of altered stands (Matlack 1994).

Evidence for another hypothesis, that former human activities affect herbaceous communities by altering habitat quality, is more equivocal. Numerous studies indicate that past land use can impart important soil legacies, such as elevated $\mathrm{pH}$ and nitrogen and phosphorus content, as well as increased bulk density (Compton \& Boone 2000; Dupouey et al. 2002; Fraterrigo et al. 2005), but consensus on how soil chemical and physical changes affect vegetation recovery in historically altered forests is still lacking. Such factors may reduce establishment (Graae et al. 2004; Verheyen \& Hermy 2004) or enhance competition among species (Honnay et al. 1999; Verheyen \& Hermy 2001; De Keersmaeker et al. 2004). Additionally, because the physiological characteristics of herbaceous species vary widely (Bazzaz \& Sultan 1987), the performance (i.e. growth) of a given species may differ in habitats whose quality has been modified by former human practices. Indeed, several studies suggest that past land use can enhance plant performance (Donohue et al. 2000; Endels et al. 2004; Verheyen \& Hermy 2004), while others have found the opposite pattern (Vellend 2005).

Biomass allocation patterns can show high plasticity in response to resource availability (Tilman 1988; Aerts \& Chapin 2000). Together with growth patterns, they may provide useful insights about how changes in site quality influence plant performance. For example, increased biomass allocation to stems, which reflects higher structural expenditure to improve light capture, may indicate that resources are abundant enough to produce dense herbaceous coverage and escalating levels of light competition (Givnish 1982). Increased allocation to leaves, on the other hand, may suggest a balance between nutrient and light limitation. Collectively, these responses may suggest how whole-plant strategies change with disturbance to maximize resource capture.

We compared patterns of above-ground biomass allocation and growth among mature herbaceous plants established in areas with different land-use histories. To examine the hypothesis that land use influences aboveground production by altering nutrient availability, we controlled for direct differences in light availability that could have affected plant response. We expected that plant growth would be positively related to nutrient availability, but that species would differ in the magnitude of their response to resource variation because of species-specific nutrient requirements and differences in nutrient acquisition capacity.

\section{Materials and methods}

\section{STUDY AREA AND LAND-USE HISTORY}

Our study was conducted in closed-canopy covehardwood forests located in the Dillingham Creek watershed of the French Broad River Basin in Buncombe County, western North Carolina, USA. Soils are well drained, upland, mountain soils derived predominately from granite, gneiss and mica-schist, and are classified as Typic Dystrudepts with humid moisture regimes (USDA NRCS). The area receives an average of 1120 $\mathrm{mm}$ precipitation annually and has a mean annual temperature of $13{ }^{\circ} \mathrm{C}$ (State Climate Office of North Carolina). Vegetation is characteristic of the mixed mesophytic communities of the Southern Blue Ridge Province described by Braun (1950), with canopies dominated by Liriodendron tulipifera L., Acer saccharum Marshall, Acer rubrum L., Quercus spp. L., Tilia americana L., Carya spp. Nuttall and Betula lenta L.

Historical land use in the southern Appalachians includes both agriculture and logging. Fields cleared by girdling the native trees were immediately planted with crops but, as productivity declined, became used as a pasture for cattle, sheep and hogs (Otto 1987). Intensive logging became prevalent in the early $1900 \mathrm{~s}$ after railroad expansion opened the region to land speculation (Eller 1982). Clearcutting contributed to the denudation of substantial tracts of land, either directly or as a consequence of skidding. In 1930, however, socio-economic changes encouraged migration to industrialized areas, and many lands were abandoned. The government purchased $>1.6$ million ha of this land, initiating the reforestation of vast areas throughout southern Appalachia. 
550

J. M. Fraterrigo,

M. G. Turner \&

S. M. Pearson

Table 1 Characteristics of the study plots and study design, including blocking structure, past land use, elevation and soil texture in western North Carolina, USA

\begin{tabular}{|c|c|c|c|c|c|c|c|}
\hline Block & Site & Plot & Land-use history & Elevation (m) & Sand $(\%)$ & Silt (\%) & Clay $(\%)$ \\
\hline \multirow[t]{2}{*}{1} & Staire Branch 1 & A & Farmed & 861 & 63 & 27 & 10 \\
\hline & Staire Branch 2 & A & Logged & 906 & 56 & 34 & 10 \\
\hline \multirow[t]{6}{*}{2} & Picnic Area & A & Farmed & 812 & 60 & 29 & 11 \\
\hline & & B & Farmed & 836 & 56 & 31 & 13 \\
\hline & & $\mathrm{C}$ & Farmed & 812 & 63 & 25 & 12 \\
\hline & Little Andy & A & Logged & 894 & 66 & 24 & 10 \\
\hline & & B & Logged & 921 & 64 & 27 & 9 \\
\hline & & $\mathrm{C}$ & Logged & 924 & 74 & 19 & 7 \\
\hline \multirow[t]{2}{*}{3} & Corner Rock & A & Logged & 1024 & 71 & 21 & 8 \\
\hline & Glassmine & A & Reference & 1076 & 74 & 18 & 8 \\
\hline \multirow[t]{6}{*}{4} & Big Andy & A & Logged & 1148 & 64 & 25 & 11 \\
\hline & & B & Logged & 1152 & 69 & 23 & 8 \\
\hline & & $\mathrm{C}$ & Logged & 1124 & 61 & 27 & 12 \\
\hline & Walker Cove & A & Reference & 1182 & 60 & 29 & 11 \\
\hline & & B & Reference & 1139 & 60 & 28 & 12 \\
\hline & & $\mathrm{C}$ & Reference & 1182 & 72 & 20 & 8 \\
\hline
\end{tabular}

\section{SITE SELECTION}

We located eight, north-facing sites on public lands (US Forest Service). Site histories were determined by landowner interviews, historical records, physical evidence and a chronosequence of aerial photographs (Pearson et al. 1998; Fraterrigo et al. 2005). Past land use varied among sites and included previously farmed areas used from 1850 to 1930 (Haile 1979) and logged standsclearcut in 1950 with mechanical skidders (SAMAB 1996), but all were at least 50 years old. We also included stands that had escaped farming and logging, which showed little or no evidence of human disturbance and contained plant species that are typical of old-growth forest (e.g. Dryopteris goldiana (Hooker) Gray), as reference areas for nearby altered sites.

Land-use history varied with elevation. Former farms were found at low elevations, reference areas at high elevations and logged stands at both low and high elevations. We paired sites at similar elevations and slopes (i.e. previous pastures with logged sites and logged sites with reference sites) to control for effects associated with these factors (Table 1). Depending on the sizes of sites, one or three $20 \times 20 \mathrm{~m}$ plots were established in each of the sites in a pair (total plots $n=16$; Table 1). Plots within sites were located in areas that differed environmentally so as to ensure independence. Plots were also located outside recent canopy gaps and hemlock (Tsuga canadensis L.) and rhododendron (Rhododendron maximum L.) thickets to avoid biasing measurements.

(C) 2006 The Authors Journal compilation (C) 2006 British Ecological Society, Journal of Ecology, 94, 548-557

\section{ABIOTIC CHARACTERISTICS}

Five soil samples were collected from the upper $15 \mathrm{~cm}$ of mineral soil during June 2002 with a $5.2-\mathrm{cm}$ diameter cylindrical PVC corer. Soil properties (bulk density,
$\mathrm{pH}$, total carbon, total nitrogen and extractable phosphorus, calcium, potassium and magnesium) and potential net nitrogen turnover rates were determined for each core following the methods described by Fraterrigo et al. (2005). We determined canopy closure by digitizing the amount of open sky visible in hemispheric photographs of the forest canopy. One photograph was taken from a height of $1.5 \mathrm{~m}$ at each corner of each plot with a fish-eye lens mounted on a $35-\mathrm{mm}$ camera. Photographic negatives were scanned and processed to classify photographs into open sky vs. shaded pixels. Soil properties and the proportion of open-sky pixels in the photographic images were averaged by plot.

\section{VEGETATION MEASUREMENTS AND REGRESSION EQUATIONS}

Prior to collecting data, we identified 12 herbaceous species that differed in life-history characteristics but had a high frequency of occurrence in the study area (S. Pearson, unpublished data; see Appendix S1 in Supplementary Material). For each of these species, we derived regression equations for stem biomass, leaf biomass and leaf area by destructively sampling 10-15 individuals of every species (mean adjusted $r^{2}=0.95$; see Appendix S1) collected from locations outside the study area. Individual leaves and stems were measured in the field, and reweighed after oven-drying at $65^{\circ} \mathrm{C}$ to a constant mass (c. 24 hours). Digital image analysis was used to determine the leaf area of fresh leaves within 2 hours of collection (O'Neal et al. 2002).

Morphological characteristics of 10 individuals of each species were recorded in each plot. Each plot was divided into $165 \times 5 \mathrm{~m}$ subplots, and no more than two individuals were sampled from each subplot. We measured leaf length and width and stem height and diameter of the same individuals during mid-June 2002 
551

Past land use and plant allocationand growth

(C) 2006 The Authors Journal compilation (C) 2006 British Ecological Society, Journal of Ecology, 94, 548-557 (i.e. at peak biomass for most herbaceous species) and mid-June 2003. Sampling of sites was randomized to compensate for any seasonal differences in plant productivity. Percentage cover of all herbaceous species was also sampled in each plot during 2002 and 2003 using $1-\mathrm{m}^{2}$ quadrats located in the centre of each $5 \times 5$ m subplot.

We used the regression equations to estimate stem, leaf and total above-ground (stem + leaf) biomass and also calculated leaf area. To obtain a relative measure of change (growth), we subtracted the value of each parameter recorded in 2002 from the value in 2003 and divided the result by the initial value. We calculated the proportion of biomass allocated to stems or leaves by dividing stem or leaf biomass by total above-ground biomass; leaf area allocation was measured as specific leaf area (SLA) and calculated by dividing leaf area by leaf biomass. These data were averaged by species, year and plot to account for non-independent observations within plots. Percentage cover was averaged by year and plot.

\section{STATISTICAL ANALYSES}

We compared plant allocation patterns across the three land-use history categories (farmed, logged and reference) using two approaches. First, plot-level proportional data were compared with analysis of variance (ANOVA). Mixed models for plants included land use, species and land use $\times$ species as fixed effects, and block (nested in land use) and plot (nested in block $\times$ land use) as random effects. Soil characteristics were tested using a similar model, without the terms relating to species. Differences in relative plant growth and total herbaceous cover with past land use were also evaluated in this manner.

Because stem and leaf allocation can vary with plant size due to allometry and proportional measurements may not capture these relationships (McConnaughay \& Coleman 1999; Muller \& Weiner 2000), we further examined allocation patterns with respect to historical land use using analysis of covariance with plant size as a covariate (ANCOVA). Mixed models were designed as above, but with stem biomass as the covariate in the model for leaf biomass and leaf area, and leaf biomass as the covariate in the model for stem biomass. In each case, dependent variables were log or arcsine-square root transformed as appropriate to meet normality assumptions.

Initially, we evaluated differences in allocation patterns in 2002 and 2003 separately, including only individuals sampled during both years to ensure balanced comparisons between years. However, because the results were similar in both years, we then averaged individual measurements and measurements of total herbaceous cover from 2002 and 2003 and reanalysed the data.

We conducted a priori tests of differences in plant allocation and soil properties with respect to past land use using orthogonal contrasts. Indirect comparisons between farmed and reference stands were possible because logged stands occurred in each study block. Pairwise comparisons of land use $\times$ species interactions were evaluated using $F$-protected least squares differences to retain statistical power (Quinn \& Keough 2002). In addition, we examined overall relationships between relative growth, allocation patterns and soil nutrients by calculating Pearson correlation coefficients across species.

\section{Results}

\section{ABIOTIC CHARACTERISTICS}

Several soil properties varied with past land use (Table 2). Mineral soil nitrogen pools were largest in logged

Table 2 Average ( $\pm 1 \mathrm{SE}$ ) properties of $0-15 \mathrm{~cm}$ mineral soil with respect to land-use history. Values in the same row with nonmatching superscripts differ significantly $(P<0.05)$. Potential nitrogen cycling rates are from Fraterrigo et al. (2005)

\begin{tabular}{llll}
\hline & \multicolumn{2}{l}{ Past land use } & \\
\cline { 2 - 3 } Soil property & Farmed & Logged & Reference \\
\hline Bulk density $\left(\mathrm{g} \mathrm{cm}^{-3}\right)$ & $0.77(0.11)$ & $0.45(0.05)$ & $0.29(0.07)$ \\
$\mathrm{pH}$ & 5.8 & 5.4 & 5.4 \\
Carbon $\left(\mathrm{Mg} \mathrm{ha}^{-1}\right)$ & $40.4(2.72)$ & $39.7(2.12)$ & $29.7(4.65)$ \\
Nitrogen $\left(\mathrm{kg} \mathrm{ha}^{-1}\right)$ & $1465(85.1)^{\mathrm{a}}$ & $1546(83.3)^{\mathrm{b}}$ & $1169(203)^{\mathrm{c}}$ \\
Phosphorus $\left(\mathrm{kg} \mathrm{ha}^{-1}\right)$ & $3468(754)^{\mathrm{a}}$ & $1372(60)^{\mathrm{b}}$ & $1071(106)^{\mathrm{b}}$ \\
Potassium $\left(\mathrm{kg} \mathrm{ha}^{-1}\right)$ & $811(80)$ & $476(50)$ & $278(83)$ \\
Calcium $\left(\mathrm{kg} \mathrm{ha}^{-1}\right)$ & $943(121)$ & $434(64)$ & $401(118)$ \\
Magnesium $\left(\mathrm{kg} \mathrm{ha}^{-1}\right)$ & $89.1(9.25)^{\mathrm{a}}$ & $67.9(9.15)^{\mathrm{b}}$ & $44.3(21.6)^{\mathrm{c}}$ \\
$\mathrm{C}: \mathrm{N}$ & $28.5(2.20)^{\mathrm{a}}$ & $26.1(1.40)^{\mathrm{b}}$ & $26.3(1.32)^{\mathrm{c}}$ \\
$\mathrm{C}: \mathrm{P}$ & $1.58(0.15)^{\mathrm{a}}$ & $3.13(0.18)^{\mathrm{b}}$ & $2.82(0.22)^{\mathrm{b}}$ \\
$\mathrm{P}: \mathrm{N}$ & $23.9(4.73)^{\mathrm{a}}$ & $9.12(0.72)^{\mathrm{b}}$ & $9.70(0.42)^{\mathrm{b}}$ \\
Potential net nitrogen mineralization* & $9.68(4.04)^{\mathrm{a}}$ & $42.7(11.0)^{\mathrm{ab}}$ & $87.8(18.5)^{\mathrm{b}}$ \\
Potential net nitrification $\dagger$ & $10.1(4.22)^{\mathrm{a}}$ & $35.5(10.4)^{\mathrm{ab}}$ & $89.2(19.4)^{\mathrm{b}}$ \\
\hline
\end{tabular}

*Units are $\left(\mathrm{mg} \mathrm{NH}_{4}+\mathrm{NO}_{3}-\mathrm{N}\right) \mathrm{kg}$ dry soil ${ }^{-1} 28 \mathrm{~d}^{-1}$.

†Units are $\left(\mathrm{mg} \mathrm{NO}_{3}-\mathrm{N}\right) \mathrm{kg}$ dry soil ${ }^{-1} 28 \mathrm{~d}^{-1}$. 
552

J. M. Fraterrigo,

M. G. Turner \&

S. M. Pearson stands, followed by farmed and reference stands. By contrast, mineral soil phosphorus content in farmed stands was more than two times greater than in logged and reference stands. Soil magnesium pools were also largest in farmed stands, exceeding the size of those in reference stands by a factor of two. Nutrient ratios varied with land-use history as well. The ratio of soil carbon to nitrogen was significantly higher in farmed stands compared with logged and reference, suggesting that old farms were the least fertile with respect to total nitrogen. This observation was consistent with previous estimates of potential net nitrogen mineralization and nitrification rates (Table 2). However, farmed stands also had a significantly lower ratio of carbon to phosphorus and higher ratio of phosphorus to nitrogen, indicating high phosphorus availability in these areas relative to logged and reference stands. Although soils in farmed and logged stands were compacted compared with reference soils, these differences were not significant. Mean soil carbon content and $\mathrm{pH}$ also did not vary with past land use.

Canopy closure ranged from 90 to $92 \%$ and did not differ with historical land use $(F=0.51, P=0.51)$, suggesting that plants experienced similar light environments regardless of previous stand management.

\section{TOTAL COVER AND ALLOCATION PATTERNS}

Total herbaceous cover was significantly reduced in areas formerly subjected to farming and logging. Mean cover was $78 \%$ in reference stands, $51 \%$ in logged stands and $58 \%$ in farmed stands $(F=95.4, P<0.001)$. Pairwise differences between reference and farmed, and reference and logged stands, were significant, whereas those between logged and farmed stands were not.

Of the 1255 individual plants sampled in 2002, 1076 $(86 \%)$ were relocated and resampled in 2003 . The proportional biomass and leaf area of these individuals suggested that past land use had an enduring influence on plant allocation patterns (Table 3, Fig. 1). The proportion of above-ground biomass allocated to stems was highest in reference stands followed by farmed stands, but an a priori hypothesis test showed no significant differences between histories (Fig. 1a) Accounting for allometric relationships resulted in somewhat different findings. Contrasts revealed that
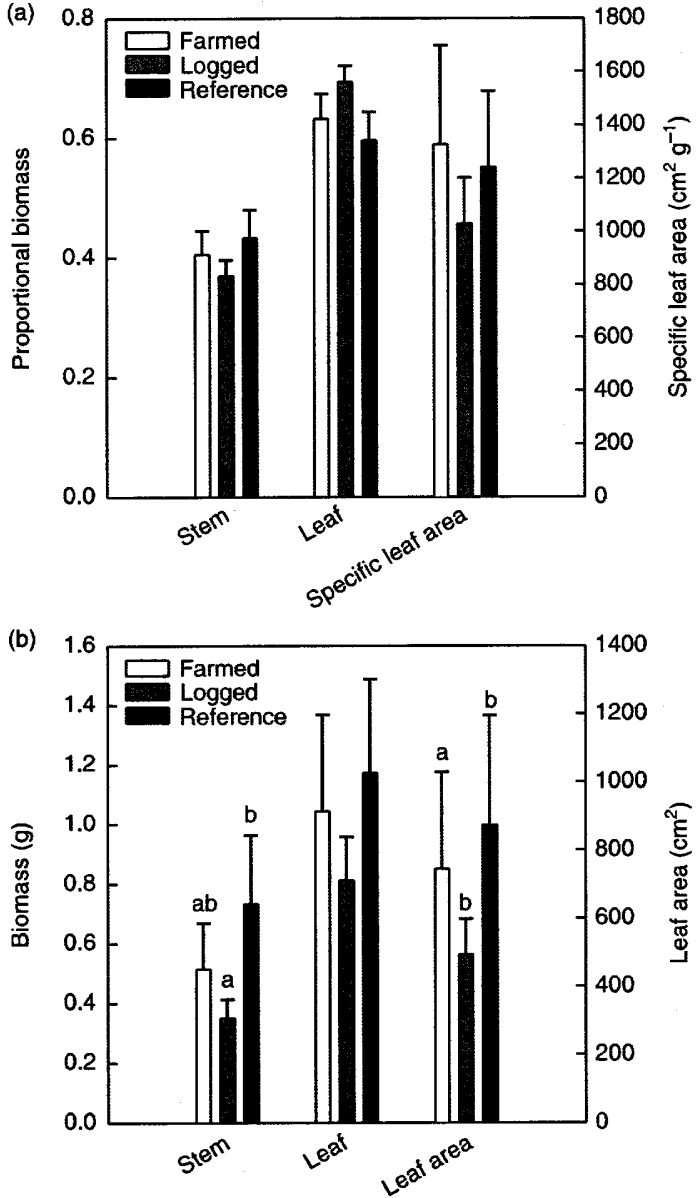

Fig. 1 Mean ( \pm 1 SE) proportional biomass in stems, leaves and leaf area (a) as well as mean steam and leaf biomass and mean leaf area (b). Values are averaged over species and years with respect to past land use. Different lowercase letters above bars indicate significant differences between land-use histories within each response group based on orthogonal contrasts. Significant differences in panel $\mathrm{b}$ account for plant allometry.

stem allocation in logged areas was significantly lower than in reference areas $(F=5.93, P=0.05$; Fig. $1 b)$, even though the overall effect of past land use was not significant when leaf biomass was included as a covariate in the model (Table 3). Leaf allocation varied significantly with past land use regardless of whether allometry was considered (Table 3); however, there were no significant pairwise differences in leaf allocation patterns among land-use histories under either

Table 3 Results of an analysis of variance (ANOVA) and an analysis of covariance (ANCOVA) on the allocation patterns of herbaceous species located in forest stands subjected to different land-use histories

(c) 2006 The Authors Journal compilation (C) 2006 British

Ecological Society, Journal of Ecology, 94, 548-557
Source of variation in ANOVA

Past land use

\begin{tabular}{|c|c|c|c|c|c|c|c|c|c|c|c|c|}
\hline \multirow[b]{2}{*}{ Response variable } & \multicolumn{3}{|c|}{ Past land use } & \multicolumn{3}{|c|}{ Past land use $\times$ species } & \multicolumn{3}{|c|}{ Past land use } & \multicolumn{3}{|c|}{ Past land use $\times$ species } \\
\hline & d.f. & $F$ & $P$ & d.f. & $F$ & $P$ & d.f. & $F$ & $P$ & d.f. & $F$ & $P$ \\
\hline Stem allocation & 2,66 & 27.2 & 0.05 & 12,66 & 3.70 & 0.0003 & 2,65 & 61.7 & 0.14 & 12,65 & 3.59 & 0.0004 \\
\hline Leaf allocation & 2,66 & 27.2 & 0.05 & 12,66 & 3.70 & 0.0003 & 2,65 & 5.79 & 0.05 & 12,65 & 2.97 & 0.002 \\
\hline Leaf area allocation & 2,66 & 3.35 & 0.12 & 12,66 & 1.68 & 0.09 & 2,65 & 4.60 & 0.06 & 12,65 & 2.20 & 0.02 \\
\hline
\end{tabular}

Source of variation in ANCOVA 
Past land use and plantallocation and growth model. Leaf area allocation showed a marginal difference with past land use when allometry was considered (Table 3) and varied significantly between farmed stands and logged and reference stands (farm. vs. logged $F=7.07, P=0.04$; farm. vs. reference $F=22.2$, $P=0.005$; Fig. 1 b).

For all measures except SLA, we consistently observed strong interactions between past land use and species, suggesting that the effect of past land use on allocation patterns depended on species (Table 3). Most species in historically farmed and logged stands, including Arisaema triphyllum (L.) Schott, Aster divaricatus L., Astilbe biternata (Vent.) Britton, Chimaphila maculatum (L.) Pursh, Galearis spectabilis L. and Osmorhiza spp. Raf., allocated less to stems, leaves and leaf area, although differences were not significant for C. maculatum and G. spectabilis (Table 4). A few species (Polygonatum spp. Miller, Prenanthes altissima L. and Sanguinaria canadensis L.) showed the opposite pattern, allocating more to stems, leaves and leaf area in old farms compared with reference stands, but these differences were not statically significant (Table 4).

\section{RELATIVE PLANT GROWTH}

Past land use had various effects on relative changes in plant biomass (Table 5). Relative stem growth was significantly higher in former farms compared with logged stands $(F=15.4, P=0.01)$ and reference stands ( $F=7.30, P=0.04$; Fig. 2 ), with little variation among species. Farmed stands showed a similarly large gain in leaf biomass compared with logged and reference stands (Fig. 2), but these differences were weak statistically (farmed vs. logged $F=5.20, P=0.07$; farm vs. reference $F=1.80, P=0.23$ ). Changes in total aboveground biomass and leaf area were highest in farmed and lowest in reference stands (Fig. 2), but did not vary significantly with past land use.

An interaction between past land use and species indicated that the effects of historic activities on rela-

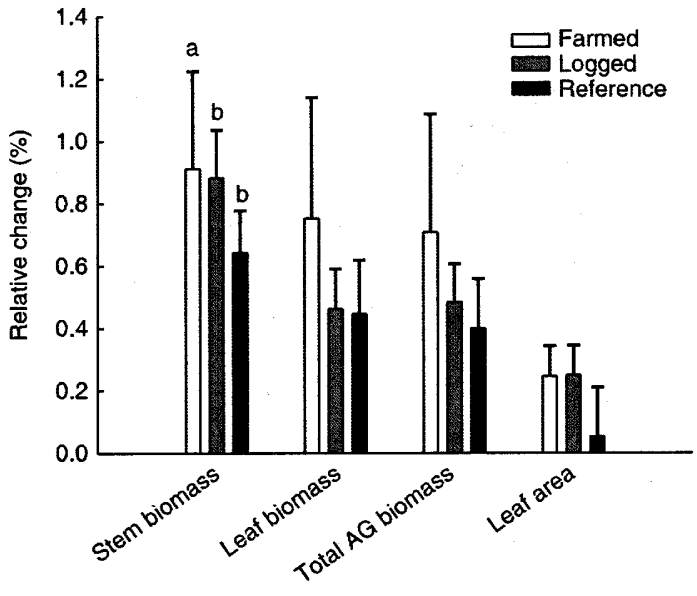

Fig. 2 Relative changes in stems, leaves, total above-ground biomass and leaf area. Relative changes, calculated as (2003 value-2002 value)/2002 value, represent an annual rate of change for each component.

tive total above-ground growth varied among species (Table 5). Aster divaricatus and S. canadensis showed significantly more growth in previously farmed and logged stands compared with reference stands, whereas Cimicifuga racemosa (L.) Nutt. showed significantly less growth.

The relationships between relative plant growth, plant allocation patterns and soil nutrients also varied with land-use history. Across species, relative aboveground growth was positively correlated with stem allocation (Fig. 3), soil nitrogen concentration ( $R=0.37, P=0.01)$ and soil phosphorus concentration $(R=0.27, P<0.01)$ in reference stands, but was unrelated to allocation patterns or nutrient concentrations in logged and farmed stands. In contrast, SLA showed a positive relationship with above-ground growth regardless of land-use history. The relationship was highly significant in reference stands (Fig. 3) and logged stands $(R=0.40, P<0.01)$, and strong but non-significant in farmed sites $(R=0.33, P=0.13)$.

Table 4 Mean ( \pm 1 SE) biomass and leaf area of herbaceous species with respect to past land use, averaged over 2002 and 2003. Land-use histories are farmed, logged and reference. Values in the same row with non-matching superscripts are significantly different $(P=0.05)$ based on $F$-protected LSD tests accounting for plant allometry

\begin{tabular}{|c|c|c|c|c|c|c|c|c|c|}
\hline \multirow[b]{2}{*}{ Species } & \multicolumn{3}{|c|}{ Stem biomass (g) } & \multicolumn{3}{|c|}{ Leaf biomass (g) } & \multicolumn{3}{|c|}{ Leaf area $\left(\mathrm{cm}^{2}\right)$} \\
\hline & Farmed & Logged & Reference & Farmed & Logged & Reference & Farmed & Logged & Reference \\
\hline Arisaema triphyllum & $0.17(0.03)^{\mathrm{a}}$ & $0.15(0.01)^{\mathrm{a}}$ & $0.43(0.09)^{\mathrm{b}}$ & $0.02(0.004)$ & $0.02(0.003)$ & $0.03(0.003)$ & $65.9(12.5)$ & $53.5(3.2)$ & $97.1(8.9)$ \\
\hline Aster divaricatus & $0.14(0.05)^{\mathrm{a}}$ & $0.12(0.05)^{\mathrm{a}}$ & $0.28(0.17)^{\mathrm{b}}$ & $0.19(0.02)$ & $0.22(0.02)$ & $0.31(0.04)$ & $136(14.4)^{\mathrm{a}}$ & $155(14.2)^{\mathrm{b}}$ & $214(20.7)^{\mathrm{a}}$ \\
\hline Astilbe biternata & 0 & $0.55(0.10)$ & $0.99(0.28)$ & 0 & $1.71(0.26)^{\mathrm{a}}$ & $2.72(0.13)^{\mathrm{b}}$ & 0 & $997(138)^{a}$ & $1558(52.7)^{\mathrm{b}}$ \\
\hline Chimaphila maculatum & $0.07(0.01)$ & $0.10(0.00)$ & 0 & $0.09(0.04)$ & $0.11(0.00)$ & 0 & $8.5(0.4)^{\mathrm{a}}$ & $9.6^{\mathrm{b}}$ & 0 \\
\hline Cimicifuga racemosa & $2.43(0.31)^{\mathrm{a}}$ & $1.42(0.31)^{\mathrm{b}}$ & $2.78(1.11)^{\mathrm{a}}$ & $5.54(0.34)$ & $4.38(0.30)$ & $4.80(0.50)$ & $4820(505)$ & $3064(333)$ & $4348(1398)$ \\
\hline Disporum lanuginosum & $0.37(0.23)$ & $0.27(0.02)$ & $0.56(0.23)$ & $0.95(0.50)$ & $0.73(0.04)$ & $1.22(0.32)$ & $506(265)$ & $348(16.0)$ & $553(157)$ \\
\hline Goodyera pubscens & 0 & 0 & 0 & $0.25(0.09)$ & $0.27(0.04)$ & $0.16(0.00)$ & $25.8(5.9)$ & $35.4(5.0)$ & 21.2 \\
\hline Galearis spectabilis & 0 & 0 & 0 & $0.11(0.00)$ & $0.16(0.03)$ & $0.36(0.00)$ & 42.7 & $54.0(8.6)$ & 116 \\
\hline Osmorhiza sp. & $0.06(0.01)$ & $0.17(0.03)$ & $0.30(0.10)$ & $0.15(0.06)$ & $0.12(0.02)$ & $0.13(0.03)$ & $137(32.9)^{\mathrm{a}}$ & $151(34.4)^{b}$ & $179(36.5)^{\mathrm{b}}$ \\
\hline Polygonatum sp. & $0.48(0.19)$ & $0.17(0.04)$ & $0.16(0.06)$ & $1.45(0.55)$ & $0.60(0.15)$ & $0.55(0.22)$ & $334(117)$ & $153(31.9)$ & $145(48.5)$ \\
\hline Prenanthes altissima & $0.15(0.03)$ & $0.09(0.02)$ & $0.10(0.05)$ & $0.22(0.03)$ & $0.14(0.02)$ & $0.14(0.08)$ & $160(18.2)$ & $107(15.5)$ & $109(59.2)$ \\
\hline Sanguinaria canadensis & $0.13(0.01)$ & $0.12(0.01)$ & $0.12(0.00)$ & $0.25(0.04)$ & $0.23(0.02)$ & $0.22(0.00)$ & $113(15.0)$ & $104(6.5)$ & 102 \\
\hline
\end{tabular}


J. M. Fraterrigo, M. G. Turner \& S. M. Pearson

Table 5 Results of an analysis of variance (ANOVA) on the relative growth of herbaceous species located in forest stands subjected to various land-use histories

\begin{tabular}{|c|c|c|c|c|c|c|}
\hline & \multicolumn{3}{|c|}{ Past land use } & \multicolumn{3}{|c|}{ Past land use $\times$ species } \\
\hline Response variable & d.f. & $F$ & $P$ & d.f. & $F$ & $P$ \\
\hline Stem biomass & 2,62 & 6.98 & 0.02 & 12,62 & 1.21 & 0.29 \\
\hline Leaf area & 2,40 & 3.16 & 0.12 & 10,40 & 1.86 & 0.08 \\
\hline Total above-ground biomass & 2,50 & 1.54 & 0.27 & 10,50 & 2.38 & 0.02 \\
\hline
\end{tabular}

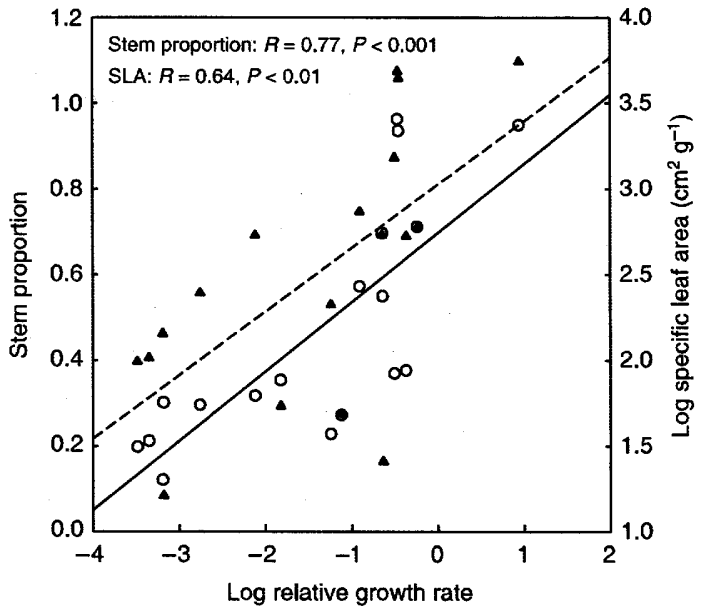

Fig. 3 The relationship between relative growth rate, stem proportion (open circles) and specific leaf area (SLA, closed triangles) in reference stands. A least squares regression line is presented for stem proportion (solid line) and SLA (dashed line).

\section{Discussion}

The comparison between reference stands and stands that were historically farmed or logged suggests that human activities continue to influence soil nutrient levels, herbaceous plant allocation and relative growth, and, importantly, the relationships among these variables, for at least 55-75 years after practices have ceased By evaluating the same late-successional species in every stand and accounting for allometry, differences in these responses could be evaluated without the confounding effects of variation in plant size. We found that plants in former farms and cutovers have higher rates of relative growth than logged and reference stands, despite allocating less energy to structures assisting in light capture and photosynthesis. In addition, we observed that the relative growth of plants in farmed and logged stands showed no relationship with stem biomass, soil nitrogen or soil phosphorus, while these variables were associated in reference stands. These results support the idea that habitat quality changes due to past land use can directly and positively affect herbaceous plant performance. However, inter- actions between past land use and species suggest that not all species respond to changes in habitat quality the same way.

Although canopy closure was similarly dense among stands that varied in land-use history, plants in farmed and logged stands showed patterns of growth that were more typical of plants in open habitat conditions, allocating relatively less to stems and more to leaves than plants in reference stands. In rich forests with highly shaded understories, a pattern of increasing height is typical of many herbs because it can enhance photosynthetic light capture and diminish the amount of light intercepted by neighbouring competitors (Givnish 1982; Gilliam \& Roberts 2003). Leaf height may have thus conveyed a competitive advantage to plants in the more densely populated understories of reference stands. However, in plant communities where coverage is sparse, there is no advantage in growing tall by allocating more to stems. Structural costs associated with increasing leaf height are not recouped with greater energy capture, resulting in an overall loss of photosynthetic advantage (Givnish 1982; Bloom et al. 1985). The reduced allocation to stems by plants in farmed and logged stands was therefore consistent with the lower understorey coverage in these areas. Moreover, it may have promoted a higher relative growth rate in these plants compared with those in reference stands by allowing greater allocation to leaves, as leaf morphology can positively influence growth (Hunt \& Cornelissen 1997). The observed positive relationship between leaf area and relative growth rate lends support to this hypothesis and agrees with studies showing an association between specific leaf area and growth (Schippers \& Olff 2000).

Given the lack of variation in light availability and the absence of a relationship between soil nutrients and plant growth in farmed and logged stands, the most parsimonious explanation for differences in understorey coverage is that farmed and logged stands have not had adequate time to develop as dense an understorey as reference stands. Many of the species found in these stands have slow intrinsic growth rates due to delayed reproduction or clonal habits (Bierzychudek 1982). For example, Donohue et al. (2000) found that Gaultheria procumbens, a woody clonal understorey species,
Ecological Society, 94, 548-557 Journal compilation (C) 2006 British 
Past land use and plantallocationand growth

(C) 2006 The Authors Journal compilation (C) 2006 British Ecological Society, Journal of Ecology, 94, 548-557 spread only $20-43 \mathrm{~cm}_{\text {year }}{ }^{-1}$ in previously cultivated stands. Thus, the understories of farmed and logged stands may have sparser coverage than reference stands for several centuries.

Soil resources also appear to have played a role in altering the growth patterns of plants in historically modified habitats. Farmed sites had considerably higher soil phosphorus, but less soil nitrogen than logged and reference stands. Although we found that plant growth in reference stands was strongly dependent on nutrient concentrations, there was no correlation between growth rate and soil nitrogen and phosphorus in farmed and logged stands. The lack of relationship between measured soil variables and growth suggests that plants were not being limited by nutrients in farmed and logged areas. Moreover, the higher rate of growth in farmed stands compared with logged stands, which had similar understorey coverage but lower nitrogen content, may indicate that light and nutrient competition was more relaxed in former farms than logged stands to the extent that it gave a performance advantage to herbaceous species inhabiting previously farmed areas. Collectively, these results provide more evidence for Olivier \& Larson's (1996) assertion that differences in plant density can alter the competitive balance among species and in turn lead to different successional trajectories.

The observed allocation and growth patterns do not generally correspond with the morphological changes expected in succeeding plant communities on rich soils (Bazzaz 1979). Early in succession, when these habitats are open, fast-growing, leafy species with low allocation to stem gain an initial but transient period of dominance (Tilman 1988; Gleeson \& Tilman 1990). Nutrient competition is low because availability is relatively balanced with (or even exceeds) plant demand (Tilman 1985). As succession proceeds and canopies close, however, fast-growing species are displaced by taller, more slowly growing plants that allocate more to stem and less to leaf or root in order to compete for light (Tilman 1988). Competition for nutrients also increases as demand overtakes supply, resulting in nutrient limitation. Thus, given the age ( $>50$ years) and maturity (closed canopies) of the previously farmed and logged stands investigated in this study, it is surprising to find that the morphologies of plants in these areas still resemble those typical of forests at earlier stages of succession.

Nonetheless, our results agree with optimal partitioning models, which suggest that plants respond to variation in the environment by partitioning biomass among various organs to optimize the capture of resources, such as nutrients and light, in a way that maximizes plant growth rate (Thornley 1972; Bloom et al. 1985; Robinson 1986). Although optimal partitioning has been called into question recently because allocation patterns can also be explained allometrically (McConnaughay \& Coleman 1999; Muller \& Weiner 2000), our study indicates that plants respond to land- use driven resource variation by preferentially allocating energy. This finding is consistent with other studies showing that, even when allometry is accounted for, allocation can vary with abiotic conditions (Bruna et al. 2002; Shipley \& Meziane 2002). We did not investigate below-ground structures (i.e. root growth) in this study, but a review of trenching experiments in temperate forests on moist, nutrient-rich soils suggests that below-ground dynamics are less important than in water-limited systems (Coomes \& Grubb 2000). Still, studies of both above- and below-ground structures are needed to test whether optimal partitioning predictions fully apply in historically altered forests.

Our conclusions about the effects of former human activities on plant performance also generally agree with those from other studies that have examined the influence of land-use history on plant communities. In examining the response of $G$. procumbens to historical agriculture, Donohue et al. (2000) suggested that past practices positively affected the demography of the species by changing abiotic factors or community structure. They found that G. procumbens populations in previously cultivated areas exhibited reduced stem mortality, and increased germination, seedling longevity and proportion of potentially reproductive stems, compared with populations in uncultivated areas. Verheyen \& Hermy (2004) likewise found that the performance of some adult herbaceous plants was better in forest stands that had been enriched by nutrients through historical agriculture, particularly when neighbouring vegetation was cleared. Endels et al. (2004) showed that adult performance was better in recent forests compared with ancient forests, but also found lower adult density, which they suggested was due to reduced seedling and juvenile survival. Indeed, others have found that increased soil phosphorus can escalate above-ground competition and presumably limit the growth of native herbs by stimulating the growth of competitively dominant species (i.e. Urtica dioica; Honnay et al. 1999; Verheyen \& Hermy 2001; De Keersmaeker et al. 2004). However, De Keersmaeker et al. (2004) also showed that shade could keep these populations in check, and thereby reduce the indirect, negative effects of soil phosphorus enrichment on woodland species. We found no indication of competitive exclusion in the forests we studied, which further suggests that plant coverage and soil nutrient availability were responsible for the differences in plant allocation and growth among stands varying in history.

\section{Conclusions}

Multiple factors can determine plant community composition, including propagule availability, biotic interactions and abiotic constraints (Newman 1973; Barot 2004). In human-altered forests, the effect of propagule availability on species distribution has been well documented. Dispersal limitation and spatial segregation of source populations have each been implicated in 
556

J. M. Fraterrigo,

M. G. Turner \&

S. M. Pearson regulating the composition of reforested stands (Matlack 1994; Brunet \& von Oheimb 1998; Verheyen et al. 2003). Sowing and transplant experiments have also demonstrated that the absence of many species is caused by seed limitation (Eriksson \& Ehrlen 1992; Turnbull et al. 2000; Mabry 2004). Thus, propagule availability has probably influenced the plant community in our farmed stands, even though the communities in logged stands show few long-term effects on diversity (Pearson et al. 1998).

Competition for light and nutrients can further structure understorey communities by limiting the occurrence and abundance of species (Gilliam \& Roberts 2003). Our results indicate that land-use-mediated changes in understorey coverage and nutrient availability can enhance the performance of plant species in formerly farmed and logged areas, perhaps by reducing the demand for these resources. However, Verheyen \& Hermy (2004) showed that species transplanted to reforesting stands performed with mixed success due to differences in competitive ability. We also observed that species differed in their allocation patterns and growth rates with respect to past land use, suggesting that species may vary in how they respond to anthropogenic disturbance. This may be due to physiological variation in nutrient requirements and acquisition capacity. Direct, long-term experiments should address the implications of differences in growth rates and interspecific variation for understorey herbaceous communities in human-altered systems.

\section{Acknowledgements}

We thank T. Givnish and M. Mack for their advice on study design. C. Mabry, F. Gilliam and two anonymous reviewers provided insightful comments on an earlier draft of this manuscript. Support for this study was provided by the Long-term Ecological Research (LTER) Program of the National Science Foundation (Grant DEB-9632854) and by a fellowship to J.M.F. from the US DOE Global Change Education Program.

\section{References}

Aerts, R. \& Chapin, F.S. (2000) The mineral nutrition of wild plants revisited: a re-evaluation of processes and patterns. Advances in Ecological Research, 30, 1-67.

Barot, S. (2004) Mechanisms promoting plant coexistence: can all the proposed processes be reconciled? Oikos, 106, 185-192.

Bazzaz, F.A. (1979) The physiological ecology of plant succession. Annual Review of Ecology and Systematics, 10, 351-371.

Bazzaz, F.A. \& Sultan, S.E. (1987) Ecological variation and the maintenance of plant diversity. Differentiation Patterns in Higher Plants (ed. K.M. Urbanska), pp. 69-93. Academic Press, London.

(C) 2006 The Authors Journal compilation (c) 2006 British Ecological Society, Journal of Ecology, 94, 548-557
Braun, L.E. (1950) Deciduous Forests of Eastern North America. Blakiston Company, Philadelphia, Pennsylvania.

Bruna, E.M., Nardy, O., Strauss, S.Y. \& Harrison, S. (2002) Experimental assessment of Heliconia acuminata growth in a fragmented Amazonian landscape. Journal of Ecology, 90, 639-649.

Brunet, J. \& von Oheimb, G. (1998) Migration of vascular plants to secondary woodlands in southern Sweden. Journal of Ecology, 86, 429-438.

Compton, J.E. \& Boone, R.D. (2000) Long-term impacts of agriculture on soil carbon and nitrogen in New England forests. Ecology, 81, 2314-2330.

Coomes, D.A. \& Grubb, P.J. (2000) Impacts of root competition in forests and woodlands: a theoretical framework and review of experiments. Ecological Monographs, 70, 171207.

De Keersmaeker, L., Martens, L., Verheyen, K., Hermy, M., De Schrijver, A. \& Lust, N. (2004) Impact of soil fertility and insolation on diversity of herbaceous woodland species colonizing afforestations in Muizen forest (Belgium). Forest Ecology and Management, 188, 291-304.

Donohue, K., Foster, D.R. \& Motzkin, G. (2000) Effects of the past and the present on species distribution: land-use history and demography of wintergreen. Journal of Ecology, 88, 303-316.

Duffy, D.C. \& Meier, A.J. (1992) Do Appalachian herbaceous understories ever recover from clearcutting? Conservation Biology, 6, 196-201.

Dupouey, J.L., Dambrine, E., Laffite, J.D. \& Moares, C. (2002) Irreversible impact of past land use on forest soils and biodiversity. Ecology, 83, 2978-2984.

Dzwonko, Z. \& Loster, S. (1992) Species richness and seed dispersal to secondary woods in southern Poland. Journal of Biogeography, 19, 195-204.

Eller, R.D. (1982) Miners, Millhands, and Mountaineers: Industrialization of the Appalachian South, 1880-1930. University of Tennessee Press, Knoxville, Tennessee.

Endels, P., Adriaens, D., Verheyen, K. \& Hermy, M. (2004) Population structure and adult plant performance of forest herbs in three contrasting habitats. Ecography, 27, 225-241.

Eriksson, O. (1995) Seedling recruitment in deciduous forest herbs: the effects of litter, soil chemistry and seed bank. Flora, 190, 65-70.

Eriksson, O. \& Ehrlen, J. (1992) Seed and microsite limitation of recruitment in plant populations. Oecologia, 91, 360-364.

Flinn, K.M. \& Vellend, M. (2005) Recovery of forest plant communities in post-agricultural landscapes. Frontiers in Ecology and the Environment, 3, 243-250.

Fraterrigo, J.M., Turner, M.G., Pearson, S.M. \& Dixon, P. (2005) Effects of past land use on spatial heterogeneity of soil nutrients in southern Appalachian forests. Ecological Monographs, 75, 215-230.

Gilliam, F.S. \& Roberts, M.R. (2003) The Herbaceous Layer in Forests of Eastern North America. Oxford University Press, New York.

Givnish, T.J. (1982) On the adaptive significance of leaf height in forest herbs. American Naturalist, 120, 353-381.

Gleeson, S.K. \& Tilman, D. (1990) Allocation and the transient dynamics of succession on poor soils. Ecology, 71, 1144-1155.

Graae, B.J., Hansen, T. \& Sunde, P.B. (2004) The importance of recruitment limitation in forest plant species colonization: a seed sowing experiment. Flora, 199, 263-270.

Haile, M.W.(1979) Dillinghams of Big Ivy, Buncombe County, NC and Related Families. Gateway Press, Baltimore, Maryland.

Honnay, O., Hermy, M. \& Coppin, P. (1999) Impact of habitat quality on forest plant species colonization. Forest Ecology and Management, 115, 157-170.

Hunt, R. \& Cornelissen, J.H.C. (1997) Components of relative growth rate and their interrelations in 59 temperate plant species. New Phytologist, 135, 395-417. 
Past land use and plant allocation and growth
Mabry, C.M. (2004) The number and size of seeds in common versus restricted woodland herbaceous species in central Iowa, USA. Oikos, 107, 497-504.

Matlack, G.R. (1994) Plant-species migration in a mixedhistory forest landscape in eastern North America. Ecology, 75, 1491-1502.

McConnaughay, K.D.M. \& Coleman, J.S. (1999) Biomass allocation in plants: ontogeny or optimality? A test along three resource gradients. Ecology, 80, 2581-2593.

Motzkin, G., Foster, D., Allen, A., Harrod, J. \& Boone, R. (1996) Controlling site to evaluate history: vegetation patterns of a New England sand plain. Ecological Monographs, 66, 345-365.

Muller, R.N. \& Weiner, J. (2000) The effect of nutrient availability on biomass allocation patterns in 27 species of herbaceous plants. Perspectives in Plant Ecology Evolution and Systematics, 3/2, 115-127.

Newman, E.I. (1973) Competition and diversity in herbaceous vegetation. Nature, 244, 310.

O'Neal, M.E., Landis, D.A. \& Isaacs, R. (2002) An inexpensive, accurate method for measuring leaf area and defoliation through digital image analysis. Journal of Economic Entomology, 95, 1190-1194.

Olivier, C.D. \& Larson, B.C. (1996) Forest Stand Dynamics. John Wiley \& Sons, New York.

Otto, J.S. (1987) Forest fallowing in the southern Appalachian Mountains. Culture and Agriculture, 33, 1-4.

Pearson, S.M., Smith, A.B. \& Turner, M.G. (1998) Forest patch size, land use, and mesic forest herbs in the French Broad River Basin, North Carolina. Castanea, 63, 382-395.

Peterken, G.F. \& Game, M. (1984) Historical factors affecting the number and distribution of vascular plant-species in the woodlands of central Lincolnshire. Journal of Ecology, 72, 155-182.

Quinn, G.P. \& Keough, M.J. (2002) Experimental Design and Data Analysis for Biologists, 2nd edn. Cambridge University Press, Cambridge.

Roberts, M.R. \& Gilliam, F.S. (1995) Disturbance effects on herbaceous layer vegetation and soil nutrients in Populus forests of northern lower Michigan. Journal of Vegetation Science, 6, 903-912.

Roberts, M.R. \& Gilliam, F.S. (2003) Response of the herbaceous layer to disturbance in eastern forests. The Herbaceous Layer in Forests of Eastern North America (eds F.S. Gilliam \& M.R. Roberts), pp. 302-320. Oxford University Press, New York.

Robinson, D. (1986) Compensatory changes in the partitioning of dry-matter in relation to nitrogen uptake and optimal variations in growth. Annals of Botany, 58, 841848.
SAMAB (Southern Appalachian Man and the Biosphere) (1996) The Southern Appalachian Assessment. Terrestrial Resources Technical Report 5. USDA Forest Service, Southern Region, Atlanta, Georgia.

Schippers, P. \& Olff, H. (2000) Biomass partitioning, architecture and turnover of six herbaceous species from habitats with different nutrient supply. Plant Ecology, 149, 219-231.

Shipley, B. \& Meziane, D. (2002) The balanced-growth hypothesis and the allometry of leaf and root biomass allocation. Functional Ecology, 16, 326-331.

Singleton, R., Gardescu, S., Marks, P.L. \& Geber, M.A. (2001) Forest herb colonization of postagricultural forests in central New York State, USA. Journal of Ecology, 89, 325-338.

Thornley, J.H. (1972) Balanced quantitative model for rootshoot ratios in vegetative plants. Annals of Botany, 36, 431-441.

Tilman, D. (1985) The resource ratio hypothesis of plant succession. American Naturalist, 125, 827-852.

Tilman, D. (1988) Plant Strategies and the Dynamics and Structure of Plant Communities. Princeton University Press, Princeton, New Jersey.

Turnbull, L.A., Crawley, M.J. \& Rees, M. (2000) Are plant populations seed-limited? A review of seed sowing experiments. Oikos, 88, 225-238.

Vellend, M. (2005) Land-use history and plant performance in populations of Trillium grandiflorum. Biological Conservation, 124, 217-224.

Verheyen, K., Guntenspergen, G.R., Biesbrouck, B. \& Hermy, M. (2003) An integrated analysis of the effects of past land use on forest herb colonization at the landscape scale. Journal of Ecology, 91, 731-742.

Verheyen, K. \& Hermy, M. (2001) An integrated analysis of the spatio-temporal colonization patterns of forest plant species. Journal of Vegetation Science, 12, 567-578.

Verheyen, K. \& Hermy, M. (2004) Recruitment and growth of herb-layer species with different colonizing capacities in ancient and recent forests. Journal of Vegetation Science, $15,125-134$.

Received 29 June 2005

revision accepted 27 September 2005

Handling Editor: Frank Gilliam

\section{Supplementary material}

The following supplementary material is available online from www.Blackwell-Synergy.com

Appendix S1 Allometric equations used to calculate plant biomass components and leaf area.
(C) 2006 The Authors Journal compilation (C) 2006 British Ecological Society, Journal of Ecology, 94, 548-557 